\title{
Comparison between resectable gastric adenocarcinomas seropositive and seronegative for Helicobacter pylori
}

\author{
W.-J. LEE, J.-T. LIN*, C.-T. SHUN†, W.-C. LEE , S.-C. YU, P.-H. LEE, K.-J. CHANG, \\ T.-C. WEI and K.-M. CHEN \\ Departments of Surgery, *Internal Medicine and $\dagger$ Pathology, National Taiwan University Hospital and $\ddagger$ College of Public Health, National \\ Taiwan University, Taiwan \\ Correspondence to: Dr K.-M. Chen, Department of Surgery, National Taiwan University Hospital, 7 Chung-Shan South Road, Taipei, Taiwan
}

The preoperative seropositivity of Helicobacter pylori was determined in 128 patients who had undergone gastrectomy for primary gastric adenocarcinoma during the past 5 years. The overall seroprevalence of $H$. pylori was 64 per cent. Gastric cancers positive for $H$. pylori were associated with tumours located in the lower third of the stomach which were of localized type (Borrmann I and II) $(P<0.05)$, but not with age, sex, blood type, tumour size, invasion depth, lymph node metastases, histological type, DNA ploidy or type of surgery. The cumulative 5-year survival curves after surgical resection were significantly better in patients who were positive for $H$. pylori. Multivariate analysis revealed that seropositivity for $H$. pylori was not an independent prognostic factor. Pathological tumour node metastasis staging was the only prognostic indicator. Better prognosis for those with $H$. pylori-seropositive gastric cancer may be attributed to the more advanced stage of $H$. pylori-seronegative gastric cancers. The potential role of $H$. pylori in gastric cancer carcinogenesis and its biological significance warrant further investigation.
Gastric cancer is common worldwide ${ }^{1}$, and surgery remains the main treatment in about half the patients ${ }^{2-4}$. The reported survival after resection varies, but Japanese studies have shown an improved survival with an overall 5 -year survival rate ranging between 40 and 50 per cent after resection ${ }^{5,6}$. The survival rate has not appreciably changed in western countries, where the overall 5-year survival rate varies between 21 and 25 per cent after resection ${ }^{3,4}$. It is possible that biological differences exist between Japanese and western patients but there are little convincing data ${ }^{7}$.

The association between previous infection with Helicobacter pylori and subsequent development of gastric cancer has been suggested from epidemiological studies $^{8-14}$. Aside from the putative role in carcinogenesis, the specific biology of gastric cancer associated with $H$. pylori may be an important clinical problem.

In the present study, the serum samples taken before operation from 128 patients who underwent gastrectomy were analysed to examine any association with the bacteria. This has allowed a retrospective assessment of the clinicopathological and prognostic association which may exist between $H$. pylori and gastric cancer.

\section{Patients and methods}

Between July 1988 and March 1993, 128 patients who had undergone gastric resection for primary gastric adenocarcinoma were studied. No patient had undergone previous treatment such as chemotherapy or radiotherapy and all patients were followed clinically for a median of 3 years. The sex and age of the patient, the location of the tumour within the stomach, tumour size as measured in the surgical specimen, gross appearance (Borrmann type), and type of surgical resection were obtained from medical records. The operations were performed according to the

Paper accepted 30 September 1994 guidelines of the Japanese Research Society for Gastric Cancer ${ }^{15}$. Radical lymph node dissection $R_{2 / 3}$ was routinely performed. When the tumour involved the proximal stomach, total gastrectomy with splenectomy and subtotal pancreatectomy was performed. The operative mortality rate was 1.6 per cent. A detailed review, including histopathological examination of available tissue slides, was performed to determine the depth of invasion on the gastric wall and the extent of metastases within regional lymph nodes. The stage was rated according to the tumour node metastasis (TNM) classification ${ }^{16}$. The histology was classified into diffuse and intestinal types in accordance with Laurén's classification ${ }^{17}$. DNA ploidy was examined by flow cytometry using fresh frozen tissue as described previously ${ }^{18}$.

Serological detection of immunoglobulin $G$ antibodies against Helicobacter pylori in serum

Serum samples were stored at $-70^{\circ} \mathrm{C}$ until examination. The presence of immunoglobulin $\mathrm{G}$ (IgG) antibodies against $H$. pylor was tested using a highly sensitive and specific enzyme-linked immunosorbent assay (ELISA: HEL-p test, AMRAD, Kew, Victoria, Australia). The antigen was an inactivated native antigen of $H$. pylori. Each serum sample was diluted 1:200. The secondary antibody was a sheep anti-human IgG-conjugated horseradish peroxidase. A specimen was considered positive for IgG antibodies to $H$. pylori if its optical density value was greater than or equal to the upper cut-off value which was calculated from positive control supplied by the manufacturer. The IgG assay had a sensitivity of 96 per cent and a specificity of 93 per cent and correlated well with other methods in detection of $H$. pylori infection ${ }^{19}$. All assays were performed without knowledge of clinical details.

\section{Statistical analysis}

Clinicopathological comparisons were made between patients positive and negative for $H$. pylori using the $\chi^{2}$ test with Yates' correction and Student's $t$ test. A $P$ value of less than 0.05 was considered to be significant. Cumulative survival rates were calculated using the Kaplan-Meier method. Analysis was performed using the Biomedical statistical package (BMDP Statistical Software, Los Angeles, California, USA). 


\section{Results}

An overall seropositivity for $H$. pylori was seen in 82 of 128 patients (64 per cent). The clinicopathological data of the resected tumours in both groups are summarized in Table 1. Significant correlations were found between the location of tumours and gross type (Borrmann) and $H$. pylori-positive gastric cancer was associated with tumours located in the lower third of the stomach which were of localized type (Borrmann I and II) $(P<0 \cdot 05)$.

There were no differences in the extent of gastric resection, operative mortality rate and provision of postoperative chemotherapy (Table 2).

Histopathological data were compared for the two groups. There were no differences in distribution of invasion depth, lymph node metastases, distant metastases, clinical stages, histological type, DNA ploidy, duodenum invasion and section line involvement.

Fig. 1 shows the survival curves of both groups after gastric resection. Patients seropositive for $H$. pylori had a better 5-year survival rate than those determined to be seronegative, but multivariate analysis using the Cox proportional hazards model revealed that TNM staging was the only significant prognostic indicator (hazard ratio $3 \cdot 122, P<0 \cdot 0001)$.

\section{Discussion}

Since the first successful culture in April 1982, H. pylori has attracted increasing attention because of its potential role in gastroduodenal diseases ${ }^{20,21}$. It is considered to be the main cause of non-autoimmune chronic antral gastritis and, therefore, may lead to the development of gastric cancer. This hypothesis has recently been suggested in many epidemiological studies ${ }^{8-14}$. In addition to its role in carcinogenesis, H. pylori might also influence the biology of this specific type of gastric carcinoma.

Although declining in incidence, gastric cancer remains the third leading cause of cancer death in Taiwan, with an annual death rate in 1990 of 15.4 and 7.2 deaths per 100000 for men and women, respectively 22 . The overall seroprevalence of $H$. pylori in Taiwan has been reported to be 54.4 per cent in a normal population, 87.4 per cent

Table 1 Clinical data of 128 patients with resectable gastric adenocarcinoma

\begin{tabular}{|c|c|c|c|c|}
\hline Variable & Positive for $H$. pylori & Negative for $H$. pylori & Total & $P$ \\
\hline $\begin{array}{l}\text { Mean(s.d.) age (years) } \\
\text { Sex ratio (M:F) }\end{array}$ & $\begin{array}{l}57(13 \cdot 6) \\
51: 31\end{array}$ & $\begin{array}{l}62(14 \cdot 5) \\
22: 24\end{array}$ & $\begin{array}{l}59(13 \cdot 7) \\
73: 55\end{array}$ & $\begin{array}{l}\text { n.s. } \\
\text { n.s. }\end{array}$ \\
\hline $\begin{array}{l}\text { Location } \\
\text { Upper } \\
\text { Middle } \\
\text { Lower }\end{array}$ & $\begin{array}{l}14(17) \\
16(20) \\
52(63)\end{array}$ & $\begin{array}{r}7(15) \\
19(41) \\
20(43)\end{array}$ & $\begin{array}{l}21 \\
35 \\
72\end{array}$ & $0 \cdot 027$ \\
\hline $\begin{array}{l}\text { Gross appearance } \\
\text { Localized (Borrmann I/II) } \\
\text { Infiltrative (Borrmann III/IV) } \\
\text { Unclassified }\end{array}$ & $\begin{array}{l}19(23) \\
43(52) \\
20(24)\end{array}$ & $\begin{array}{c}3(7) \\
36(78) \\
7(15)\end{array}$ & $\begin{array}{l}22 \\
79 \\
27\end{array}$ & 0.011 \\
\hline $\begin{array}{l}\text { Size } \\
\quad<4 \mathrm{~cm} \\
4-8 \\
>8 \mathrm{~cm}\end{array}$ & $\begin{array}{l}34(41) \\
35(43) \\
13(16)\end{array}$ & $\begin{array}{l}13(28) \\
22(48) \\
11(24)\end{array}$ & $\begin{array}{l}47 \\
57 \\
24\end{array}$ & n.s. \\
\hline $\begin{array}{l}\text { Blood type } \\
\text { A } \\
\text { B } \\
\text { O } \\
\text { AB }\end{array}$ & $\begin{array}{l}28(34) \\
14(17) \\
35(43) \\
5(6)\end{array}$ & $\begin{array}{r}15(33) \\
9(20) \\
19(41) \\
3(7)\end{array}$ & $\begin{array}{r}43 \\
23 \\
54 \\
8\end{array}$ & n.s. \\
\hline Total & $82(64)$ & $46(36)$ & 128 & \\
\hline
\end{tabular}

Values in parentheses are percentages unless otherwise stated. n.s., not significant

Table 2 Operative and postoperative data

\begin{tabular}{|c|c|c|c|c|}
\hline Variable & $\begin{array}{l}\text { Positive for } H . p y l o r i \\
(n=82)\end{array}$ & $\begin{array}{l}\text { Negative for } H . \text { pylori } \\
(n=46)\end{array}$ & $\begin{array}{l}\text { Total } \\
(n=128)\end{array}$ & $P$ \\
\hline \multicolumn{5}{|l|}{ Gastrectomy } \\
\hline Total & $20(24)$ & $17(37)$ & 37 & \multirow[t]{2}{*}{ n.s. } \\
\hline \multirow{2}{*}{\multicolumn{5}{|c|}{ Operation }} \\
\hline & & & & \\
\hline Morbidity & $17(21)$ & $16(35)$ & $33(26)$ & \multirow[t]{2}{*}{ n.s. } \\
\hline Mortality & $1(1)$ & $1(2)$ & $2(2)$ & \\
\hline \multicolumn{5}{|c|}{ Postoperative chemotherapy } \\
\hline Yes & $40(49)$ & $27(59)$ & 67 & \multirow[t]{2}{*}{ n.s. } \\
\hline No & $42(51)$ & $19(41)$ & 61 & \\
\hline \multicolumn{5}{|l|}{ Recurrence } \\
\hline Yes & $21(26)$ & $21(46)$ & 42 & \multirow[t]{2}{*}{0.038} \\
\hline No & $61(74)$ & $25(54)$ & 86 & \\
\hline
\end{tabular}

Values in parentheses are percentages. n.s., not significant 


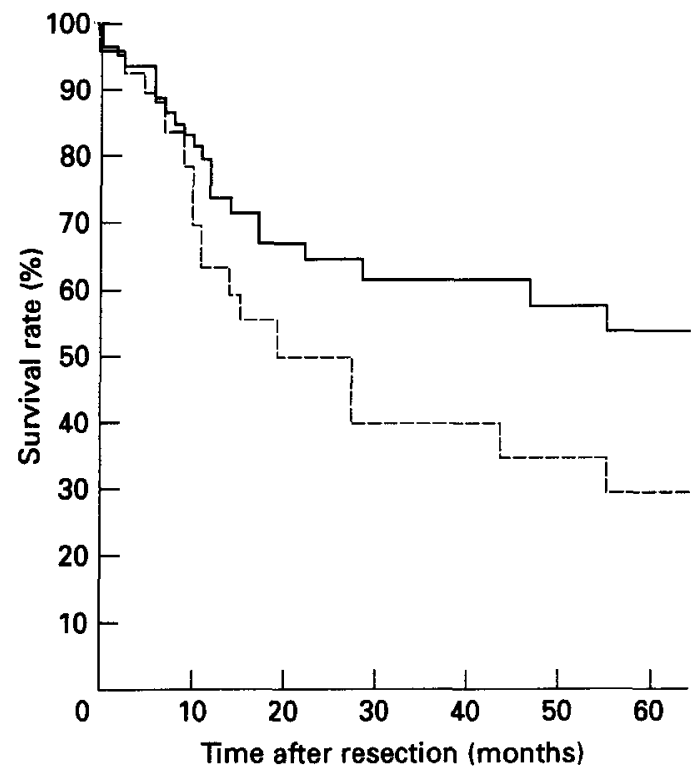

\section{No. at risk}

$\begin{array}{llllllll}\text { Seropositive } & 82 & 68 & 55 & 51 & 49 & 46 & 44 \\ \text { Seronegative } & 46 & 37 & 25 & 20 & 19 & 16 & 14\end{array}$

Fig. 1 Cumulative survival curves for 82 patients seropositive $(-)$ and 46 seronegative (-- ) for Helicobacter pylori after resection for gastric cancer. $P<0.05$ (generalized Wilcoxon test)

in those with duodenal ulcers, $76 \cdot 2$ per cent in those with gastric ulcers and 62.2 per cent in those with gastric adenocarcinoma ${ }^{23-25}$. Infection in early childhood may be a contributing factor to gastric carcinogenesis ${ }^{14}$, but $30-40$ per cent of patients with gastric cancer in Taiwan have neither recurrent nor previous infection with $H$. pylori. It would be of interest to determine differences in the behaviour of $H$. pylori between these two groups of patients.

In the present study, there were significant differences in patients with previous $H$. pylori infection with regard to the location and gross appearance of the tumours. Some researchers have noted a positive correlation between $H$. pylori infection and intestinal type metaplasia and the presence of non-cardia cancer ${ }^{11,26}$. This has not been confirmed by others ${ }^{12,27}$. The present study supports the positive association of distal site gastric cancer and $H$. pylori infection, but no difference was found between intestinal and diffuse type gastric cancer and $H$. pylori infection. This observation supports the hypothesis of Sipponen et al. ${ }^{28}$ that $H$. pylori-associated chronic gastritis provides the background for gastric cancer carcinogenesis whereas the intestinal type may be promoted by an atrophic stomach and the diffuse type by a non-atrophic gastritis mucosa. Thus, both types of gastric cancer share similar features in $H$. pylori association. The correlation of localized gross type (Borrmann type I and II) gastric carcinoma has not been reported. This finding may also imply a different biology in gastric cancer associated with $H$. pylori. The improved prognosis after surgical treatment of those with $H$. pylori-seropositive gastric cancer may reffect such differences in cancer behaviour. Although the TNM stage remained the most reliable prognostic indicator after resection, different surgical approaches may result in stage migration and thus render valid comparison between different areas difficult ${ }^{29}$.
The seroprevalence of $H$. pylori infection varies widely. For example, there were high prevalence areas of India (98 per cent) ${ }^{30}$, Brazil (94 per cent $)^{27}$ and Africa ( 85 per cent $^{31}$, and low prevalence areas in the UK (30 per cent $)^{32}$ and the Caucasian population of the USA ( 37 per cent) ${ }^{33}$. It is possible for a survival difference to exist where different environmental factors are involved in carcinogenesis. Fortner et al. ${ }^{34}$ observed a significantly poorer survival rate in patients born in the USA than that in patients born outside the USA. Their finding also implied that prognosis may vary with the role of environmental factors involved in carcinogenesis.

The present results suggest that although $H$. pylori seropositivity is not useful as a prognostic factor, it may influence the overall prognosis in different areas. $H$. pylori-seropositive gastric cancer has a better prognosis after surgical resection, which might be attributed to the more advanced stage of $H$. pylori-seronegative cancer. It might be one reason to explain the discrepancy between cancer treatment results between Japanese and Western patients. Further investigations are needed to elucidate the inherent biological characteristics and clinical significance of this specific type of gastric cancer.

\section{Acknowledgements}

This study was supported by grants from the National Science Council of the Executive Yuan of the Republic of China NSC82-0412-B002-130 and NSC-83-0412-B-002-176.

\section{References}

1 Correa P. The epidemiology of gastric cancer. World J Surg 1991; 15: 228-34.

2 Lee WJ, Lee WC, Houng SJ, Wong ML, Wei TC, Chen KM. Postresection prognosis of gastric patients: comparison of staging systems. Tzu-Chi Med J 1994; 6: 7-13.

3 Allum WH, Powell DJ, McConkey CC, Fielding JWL. Gastric cancer: a 25-year review. Br J Surg 1989; 76: 535-40.

4 Wanebo HJ, Kennedy BJ, Chmiel J, Steele G Jr, Winchester D, Osteen R. Cancer of the stomach. A patient care study by the American College of Surgeons. Ann Surg 1993; 218: 583-92.

5 Maruyama K, Okabayashi K, Kinoshita T. Progress in gastric cancer surgery in Japan and its limits of radicality. World $J$ Surg 1987; 11: 418-25.

6 Soga J, Ohyama S, Miyashita K et al. A statistical evaluation of advancement in gastric cancer surgery with special reference to significance of lymphadenectomy for cure. World J Surg 1988; 12: 398-405.

7 Behrns KE, Dalton RR, van Heerden JA, Sarr MG. Extended lymph node dissection for gastric cancer. Is it of value? Surg Clin North Am 1992; 72: 433-43.

8 Forman D, Sitas F, Newell DG et al. Geographic association of Helicobacter pylori antibody prevalence and gastric cancer mortality in rural China. Int J Cancer 1990; 46: 608-11.

9 Correa P, Fox J, Fontham E et al. Helicobacter pylori and gastric carcinoma. Serum antibody prevalence in populations with contrasting cancer risks. Cancer 1990; 66: 2569-74.

10 Forman D, Newell DG, Fullerton F et al. Association between infection with Helicobacter pylori and risk of gastric cancer: evidence from a prospective investigation. BMJ 1991; 302: 1302-5.

11 Parsonnet J, Friedman GD, Vandersteen DP et al. Helicobacter pylori infection and the risk of gastric carcinoma. N Engl J Med 1991; 325: 1127-31.

12 Talley NJ, Zinsmeister AR, Weaver A et al. Gastric adenocarcinoma and Helicobacter pylori infection. $J$ Natl Cancer Inst 1991; 83: 1734-9.

13 Nomura A, Stemmermann GN, Chyou PH, Kato I, Perez- 
Perez GI, Blaser MJ. Helicobacter pylori infection and gastric carcinoma among Japanese Americans in Hawaii. $N$ Engl $J$ Med 1991; 325: 1132-6.

14 Lin JT, Wang LY, Wang JT, Wang TH, Chen CJ. Ecological study of association between Helicobacter pylori infection and gastric cancer in Taiwan. Dig Dis Sci 1995; 40: 385-8.

15 Japanese Research Society for Gastric Cancer. The general rules for the gastric cancer study in surgery and pathology. Part I. Clinical classification; part II. Histological classification of gastric cancer. Jpn J Surg 1981; 11: 127-45.

16 International Union Against Cancer. In: Harmer $\mathrm{MH}$, ed. TNM Classification of Malignant Tumours. 3rd ed. Geneva: Springer-Verlag, 1978.

17 Laurén P. The two histological main types of gastric carcinoma: diffuse and so-called intestinal-type carcinoma. Acta Pathol Microbiol Scand 1965; 64: 31-49.

18 Lee WJ, Pu YS, Wong ML, Lin WJ, Chen KM. DNA flow cytometry in patients with operable gastric cancer. Tzu-Chi Med J 1993; 5: 239-44.

19 Wang JT, Lin JT, Sheu JC, Yang JC, Chen DS, Wang TH. Detection of Helicobacter pylori in gastric biopsy tissue by polymerase chain reaction. Eur J Clin Microbiol Inf Dis 1993; 12: $367-71$

20 Warren JR, Marshall B. Unidentified curved bacilli on gastric epithelium in active chronic gastritis. Lancet 1983; i: 1273-5.

21 Goodwin CS. Helicobacter pylori: 10th anniversary of its culture in April 1982. Gut 1993; 34: 293-4.

22 Lee WC, Lin RS. Interactions between birth cohort and urbanization on gastric cancer mortality in Taiwan. Int $J$ Epidemiol 1994; 23: 252-60.

23 Lin JT, Wang JT, Wang TH, Wu MS, Lee TK, Chen CJ. Helicobacter pylori infection in a randomly selected population, healthy volunteers, and patients with gastric ulcer and gastric adenocarcinoma. A seroprevalence study in Taiwan. Scand J Gastroenterol 1993; 28: 1067-72.

24 Lin JT, Wang JT, Wang TH, Wu MS, Chen CJ. Helicobacter pylori infection in early and advanced gastric adeno- carcinoma: a seroprevalence study in 143 Taiwanese patients. Hepatogastroenterology 1993; 40: 596-9.

25 Lin JT, Wang JT, Wu MS, Wang TH, Lee TK, Chen CJ. Seroprevalence study of Helicobacter pylori infection in patients with gastroduodenal diseases. I Formos Med Assoc 1994; 93: 122-7.

26 Parsonnet J, Vandersteen D, Goates J, Sibley RK, Pritikin J, Chang Y. Helicobacter pylori infection in intestinal- and diffuse-type gastric adenocarcinomas. J Natl Cancer Inst 1991; 83: $640-3$.

27 Nogueira AM, Ribeiro GM, Rodrigues MA et al. Prevalence of Helicobacter pylori in Brazilian patients with gastric carcinoma. Am J Clin Pathol 1993; 100: 236-9.

28 Sipponen P, Kosunen TU, Valle J, Riihela M, Seppala K. Helicobacter pylori infection and chronic gastritis in gastric cancer. J Clin Pathol 1992; 45: 319-23.

29 Lee WJ. Prognostic relevance of systematic lymph node dissection in gastric carcinoma. Br J Surg 1994; 81: 315-16 (Letter).

30 Graham DY, Adam E, Reddy GT et al. Seroepidemiology of Helicobacter pylori infection in India. Comparison of developing and developed countries. Dig Dis Sci 1991; 36: 1084-8.

31 Holcombe C, Omotara BA, Eldridge J, Jones DM. H. pylori, the most common bacterial infection in Africa: a random serological study. Am J Gastroenterol 1992; 87: 28-30.

32 Wyatt JI, Rathbone BJ. The role of serology in the diagnosis of Campylobacter pylori infection. Scand J Gastroenterol 1989; 24: 27-34.

33 Graham DY, Malaty HM, Evans DG, Evans DJ Jr, Klein PD, Adam E. Epidemiology of Helicobacter pylori in the asymptomatic population in the United States. Effect of age, race, and socioeconomic status. Gastroenterology 1991; 100: 1495-1501.

34 Fortner JG, Lauwers G, Thaler HT et al. Nativity, complications, and pathology are determinants of surgical results for gastric cancer. Cancer 1994; 73, 8-14. 